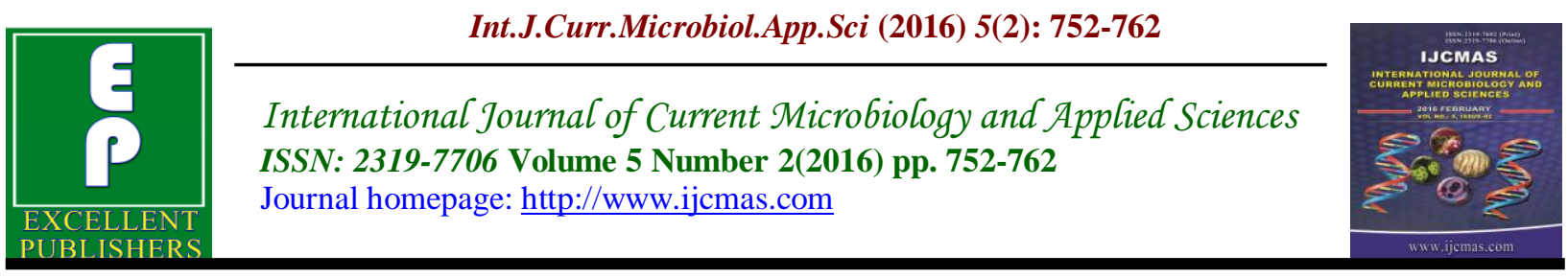

Original Research Article

doi: http://dx.doi.org/10.20546/ijcmas.2016.502.085

\title{
Markers of HCV-Related HCC in Egyptian Patients
}

\author{
Dina EIShennawy ${ }^{1}$, Nermeen Tayseer Aly Fouad ${ }^{1 *}$, Hanaa Amer ${ }^{1}$, \\ Amal T Abdel Moez ${ }^{2}$, Hanaa Fathey ${ }^{3}$, Marcel W Keddeas ${ }^{3}$ and Elewa $\mathrm{AA}^{3}$ \\ ${ }^{1}$ Clinical Pathology Department, Faculty of Medicine, Ain Shams University, Cairo, Egypt \\ ${ }^{2}$ Tropical Medicine Department, Faculty of Medicine, Ain Shams University, Cairo, Egypt \\ ${ }^{3}$ Internal Medicine Department, Faculty of Medicine, Ain Shams University, Cairo, Egypt \\ *Corresponding author
}

\begin{abstract}
A B S T R A C T
Keywords

HCV-related

HCC,

NS5A,

ISDR,

TGF- $\beta 1$,

ICAM-1

Article Info

Accepted:

28 January 2016

Available Online:

10, February 2016

At least two thirds of HCV infected cases would probably develop chronic HCV infections, and are thus at risk of developing liver cirrhosis and $\mathrm{HCC}$. We investigated the sequence of hepatitis $\mathrm{C}$ virus RNA NS5A region in HCV-related HCC patients as well as in chronic HCV patients to highlight its potential pathogenic role, and investigated the usefulness of TGF- $\beta 1$ and ICAM- 1 as serological biomarkers in the diagnosis of $\mathrm{HCV}$-related HCC. The results in this study indicated that $60 \%$ of group I (HCV-related HCC) and $23.3 \%$ of group II (chronic HCV) patients harbored a wild-type sequence of NS5A region with a significant difference between both groups. Moreover, there is significant increase in mean sequence identities in group I, compared to group II $(p<0.001)$ and significant increase in mean number of mutations in NS5A, and ISDR regions in group II ( $p<0.001)$ compared to group I, and serum TGF- $\beta 1$ and ICAM-1 levels in group I patients were significantly higher than those in group II patients $(\mathrm{p}<0.001)$. Conclusion: The wild type NS5A, particularly that of ISDR, is a significant marker for the development of HCV-related HCC. In addition, TGF- $\beta 1$ and ICAM- 1 are potential effective serological markers for the diagnosis of patients with HCVrelated $\mathrm{HCC}$.
\end{abstract}

\section{Introduction}

Hepatocellular carcinoma (HCC) is the fifth most common cancer, and the second most common digestive system malignant tumor worldwide, accounting for $5 \%$ of all cancers $(1,2)$. Hepatitis $\mathrm{C}$ virus (HCV) is considered to be the second most common cause of $\mathrm{HCC}$, accounting for $25 \%$ of HCC cases (3). In fact, $\mathrm{HCV}$ infections is a global serious health threat, as 3.5 million new HCV infected cases and 350000 deaths from HCV related diseases are reported annually (4). More than two thirds of HCV infected cases would probably develop chronic HCV infections, and are thus at risk of developing liver cirrhosis, liver cell failure and HCC (5). Despite the decrease in the prevalence of $\mathrm{HCV}$ in developed countries, the developing countries, including Egypt, still exhibit increasing prevalence rates of $\mathrm{HCV}$ infections, which is recently reported to be 
about $10-14 \%$ of Egypt's population $(3,6,7)$.

A better understanding of the molecular pathogenesis of $\mathrm{HCV}$ would indeed help to establish novel strategies for the prevention and treatment of $\mathrm{HCV}$ related diseases, including $\mathrm{HCC}$. $\mathrm{HCV}$ is a small enveloped single stranded hepatotropic RNA virus that belongs to Flaviviridae family, with its 9.6 $\mathrm{kb}$ genomic RNA consisting of 3 main regions: The highly conserved 5'UTR, an open reading frame (ORF) that encompasses about 9000 nucleotides, and the 3' UTR regions. The HCV ORF encodes a 3000 long polypeptide chain which is then cleaved into 3 structural and 7 non structural proteins, namely core, E1, E2, p7, NS2, NS3, NS4A, NS4B, NS5A, and NS5B $(8,9,10)$. It is known that the non-structural $5 \mathrm{~A}$ region (NS5A) plays an important role in promoting both the viral replication and assembly of the viral particles. It was also reported that NS5A could possibly help the virus to escape the host immune response and thus aids the virus pathogenesis and spread. Moreover, previous studies on transgenic mice demonstrated that NS5A induced genome instability, dysregulated cellular growth and signal transduction and suggested that it might have a important role in HCC pathogenesis $(11,12)$. All these findings make NS5A a critical target for antiviral drugs, but as it is known that different $\mathrm{HCV}$ genotypes exhibit different responses to $\mathrm{HCV}$ antiviral therapies, it is important to clarify the potential pathogenic role of NS5A in Egyptian population where genotype 4 is the most prevalent genotype (9).

Great efforts have been made to identify new serological biomarkers for diagnosis of HCC. It was reported that induction of chronic inflammation with increased expression of TH2 cytokines and adhesion molecules creates a neoplastic favoring microenvironment $(13,14)$. Overexpression of TGF- $\beta 1$ was reported in a number of cancers, including HCC. Though TGF- $\beta 1$ is known as a tumor suppressor that suppresses cell cycle progression in early G1 phase, misregulation of TGF- $\beta 1$ signaling promotes tumor growth, cancer cell dissemination and metastasis (5). It was also reported that HCC cells secrete increased levels of ICAM-1, that would facilitate the adhesion and movement of cancer cells and thus promote tumor development $(14,15)$.

The present work aimed to investigate the sequence of hepatitis C virus RNA NS5A in patients with chronic hepatitis $\mathrm{C}$ and in patients with HCV-related HCC to highlight its potential pathogenic role, and to investigate the usefulness of biomarkers as TGF- $\beta 1$ and ICAM- 1 in the diagnosis of $\mathrm{HCV}$ related-HCC.

\section{Materials and Methods}

This study included 30 Egyptian patients with HCV-related HCC (group I), and 30 Egyptian chronic HCV patients (group II), who attended the clinic of Oncology unitNasr City Insurance Hospital and the clinics of Tropical Medicine and Internal MedicineAin Shams University Hospitals. All group I patients were diagnosed as having HCVrelated HCC by quantitative PCR to detect HCV-RNA, AFP levels, combination of ultrasonography (US) and computed tomography (CT), and all of them had no evidence of extrahepatic metastasis. Meanwhile, all group II patients were chosen for the study after full laboratory data assessment including liver function tests, HCV-RNA detection by quantitative PCR, and genotyping, with no evidence of HCC development by AFP, US or CT. All the patients included in the present study (both group I and II) were HCV 4-a subtype which is the most prevalence subtype in 
Egypt and were negative for hepatitis B surface antigen (HBsAg).

Informed consent was obtained from all participant individuals. The study was conducted in accordance with the stipulations of the local ethical and scientific committees of Ain Shams University and the procedures respected the ethical standards in Helsinki declaration of 1964. Samples were collected from all patients and plasma and serum were stored at $-70^{\circ} \mathrm{C}$ until they were used.

All patients were subjected to:

1. Sequencing of the HCV-NS5A region (codons 2069-2265) by automated DNA sequencer (ALF express Autoread), using sequencing kit, in conjunction with ALF Express $^{\text {TM }}$ dATP labeling mix supplied by Amersham Pharmacia Biotech, Sweden.

2. Serum TGF- $\beta 1$ assay by commercially available Quantikine R\&D Human TGF- $\beta 1$ ELISA Kit (R\&D Systems, Minneapolis, MN, USA).

3. Serum ICAM-1 assay by commercially available Quantikine R\&D Human ICAM-1 ELISA Kit (R\&D Systems, Minneapolis, MN, USA).

\section{Amplification of HCV NS5A by RT-PCR and Sequence Analysis}

RNA extraction was done using QIA amp viral RNA Mini kit (QIAGEN Group), according to the manufacturer's instructions, followed by RNA reverse transcription and amplification using QIAGEN one step RTPCR kit technology, USA. Primers used for amplification of NS5A region were primer A (forward primer): CCGTACCTT GGAAGGGGTAG, and primer B (reverse primer): ACCGAGACTT CCCTGTCATC. The reverse transcription and amplification were done according to the following program: $50^{\circ} \mathrm{C}$ for 30 minutes, $95^{\circ} \mathrm{C}$ for 15 minutes, followed by 3 steps amplification cycle consisting of: $94^{\circ} \mathrm{C}$ for $1 \mathrm{~min}, 68^{\circ} \mathrm{C}$ for $1 \mathrm{~min}, 72^{\circ} \mathrm{C}$ for $1 \mathrm{~min}$, which is repeated for 40 cycles, followed by final extension at $72^{\circ} \mathrm{C}$ for $10 \mathrm{~min}$.

DNA sequence analysis for HCV NS5A region was done using ALF express Autoread sequencing kit, in conjunction with ALF Express ${ }^{\text {TM }}$ dATP labeling mix supplied by Amersham Pharmacia Biotech, Sweden. This process involved denaturation of the amplified DNA followed by annealing of denaturated DNA with the primers (forward primer: CCGTACCT TGGAAGGGGTAG), and (reverse primer: ACCGAGACTTCCCTGTCATC). The annealing reaction was preheated at $65^{\circ} \mathrm{C}$ for 5 minutes, then placed at $37^{\circ} \mathrm{C}$ for 10 minutes and at room temperature for 10 minutes. This was followed by addition of the labeling mix and termination reactions.

The resulting nucleotides sequencing of amplified NS5A region were translated into individual amino acid using DNA MAN program (gene bank). Then the amino acid sequence alignment relative to establish wild type NS5A protein region of $\mathrm{HCV}$-genotype 4-a sequence data base from gene bank to deduce the amino acid changes.

\section{Statistical Analysis}

Statistical analysis performed using SPSS V 15.0. Results were expressed as means \pm $\mathrm{SD}$, percentages, and ranges. Comparisons of quantitative and qualitative variables were conducted between groups using the student-t test and Chi-square tests and Fisher's exact test respectively. A p-value of $\leq 0.05$ was considered to be statistically significant while a $\mathrm{p} \leq 0.001$ was considered highly significant. 
Logistic regression analysis was performed to determine the significant effect of the different variables on the diagnosis of chronic hepatitis $\mathrm{C}$ and $\mathrm{HCV}$ related $\mathrm{HCC}$.

An operator characteristic (ROC) curve was constructed to establish clinically relevant cut off values for TGF- $\beta 1$ and ICAM-1.

\section{Results and Discussion}

The mean age of patients involved in this study was $56.23 \pm 7.4$ years, while the mean age for group I and II was $57.30 \pm 8.1$ and $55.2 \pm 6.7$ years respectively with no significant difference between both groups $(\mathrm{t}=1.11, \mathrm{p}=0.28)$. There was male predominance in both groups, with group I including 3 females and 27 males and group II including 6 females and 24 males.

The mean HCV- RNA viral load was $269433 \pm 207863$ and $294597 \pm 229284$ IU/ml for group I and group II patients respectively, with no statistically significant difference between both groups $(\mathrm{p}=0.575)$.

Demographic and descriptive laboratory data of group I and group II patients are described in table (1)

\section{Results of NS5A Sequencing}

The results in this study indicated that 18 patients $(60 \%)$ out of 30 patients of $\mathrm{HCV}$ related HCC group (group I) harbored a wild-type (wt) sequence of NS5A region with a sequence identities $(100 \%)$, while the other 12 patients $(40 \%)$ harbored mutations that ranged from $2-6$ with mean $4.5 \pm 1.38$ mutations/case and mean sequence identities $91.5 \pm 1.31 \%$. On the other hand it was found that $23 / 30(76.7 \%)$ of non HCC chronic HCV patients (group II) harbored mutations that ranged from 5 - 17 with a mean $9.5 \pm 3.01$ mutations/case and mean sequence identities $89.1 \pm 3.82 \%$.
Comparative statistics between group I and group II revealed a significant higher frequency of mutations in the NS5A region in group II patients $\left(\mathrm{X}^{2}=8.2971, \mathrm{p}=0.003\right)$. Also there was highly significant increase in mean sequence identities in group I compared to group II $(\mathrm{p}<0.001)$, and highly significant increase in mean number of mutations in group II $(\mathrm{p}<0.001)$ compared to group I (table 2).

\section{Interferon Sensitive Determining Region (ISDR) Mutations (Codons 2209-2248)}

10 out of 30 group I patients versus 23 out of 30 group II patients had ISDR mutations, with a highly significant difference between both groups $\left(\mathrm{X}^{2}=11.381, \mathrm{p}<0.001\right)$. The mean number of mutations/case in the ISDR sequence was lower in group I patients than in group II patients with a highly significant difference between both groups $(\mathrm{p}<0.001)($ table 2 and 3). The mutations in the ISDR in group II patients ranged from 17 , while none of group I patients had more than 1 ISDR mutation.

Figure (1) shows schematic representation of the amino acids sequence of the amplified NS5A region for patients involved in this study

Comparative statistics between group I and group II patients regarding the studied parameters are shown in table (2), while comparative statistics between group I and group II mutation positive patients regarding the studied parameters are shown in table (3).

Regarding the frequency of mutations in the NS5A region, it was found that mutations at codons $2260 \& 2130$ were the most frequent occurring in 21/23 group II and 8/12 group I patients who harbored NS5A mutations. Meanwhile, mutation at codon 2212 was the most frequent mutation in ISDR region 
occurring in 19/23 group II patients and in 9/12 group I patients who harbored NS5A mutations.

\section{Results of TGF- $\beta 1$ and ICAM-1}

The present study results showed that the mean TGF- $\beta 1$ and ICAM-1 levels in the group I patients were significantly higher than those in group II patients (both $\mathrm{p}<0.001)$. The serum levels of TGF- $\beta 1$ and ICAM-1 in group I ranged from 5,700 $16,500 \mathrm{pg} / \mathrm{ml}$ and from 210 to $1580 \mathrm{ng} / \mathrm{ml}$ respectively with a mean of $9971 \pm 2554$ $\mathrm{pg} / \mathrm{ml}$ and $633 \pm 331 \mathrm{ng} / \mathrm{ml}$, while the serum levels of TGF- $\beta 1$ and ICAM-1 in group II ranged from $1,570-10,800 \mathrm{pg} / \mathrm{ml}$ and from 170 to $560 \mathrm{ng} / \mathrm{ml}$ respectively with a mean of $5708 \pm 2331 \mathrm{pg} / \mathrm{ml}$ and $339 \pm$ $108 \mathrm{ng} / \mathrm{ml}$. Using ROC analysis, a cut off of TGF- $\beta 1$ of $7210 \mathrm{pg} / \mathrm{ml}$ was found to discriminate $\mathrm{HCC}$ - related $\mathrm{HCV}$ patients from non $\mathrm{HCC}$ related $\mathrm{HCV}$ patients with sensitivity $93.3 \%$ and specificity $80 \%$, while a cut off of ICAM-1 of $445 \mathrm{ng} / \mathrm{ml}$ could discriminate $\mathrm{HCC}$ - related $\mathrm{HCV}$ patients from non $\mathrm{HCC}$ related $\mathrm{HCV}$ patients with sensitivity $73.3 \%$ and specificity $83.3 \%$ (figure 2). Comparative statistics of serum levels of TGF- $\beta 1$ and ICAM-1 are presented in (tables 1 and 2)

\section{Logistic Regression}

The results of regression analysis showed that serum TGF- $\beta 1$ levels, serum ICAM-1 levels, and number of NS5A mutations are the significant variables for the diagnosis of HCV-related HCC $(p=0.004, p=0.02$, and $\mathrm{p}=0.01$ respectively).

Table.1 Demographic and Descriptive Laboratory Data of Group I and Group II Patients

\begin{tabular}{|c|c|c|}
\hline Parameter & Group I & Group II \\
\hline Age (years) & $\leq 55: 11(36.7 \%)$ & $\leq 55: 16(53.3 \%)$ \\
Sex & $>55: 19(63.3 \%)$ & $>55: 14(46.7 \%)$ \\
& Male: $27(90 \%)$ & Male: $24(80 \%)$ \\
Female: $3(10 \%)$ & Female: $6(20 \%)$ \\
HCV viral load (IU/ml) & Range: $2800-6,20000$ & Range: $1200-5,45000$ \\
NS5A sequence & wt: $18(60 \%)$ & wt: $7(23.3 \%)$ \\
& 1-6 mutations: $12(40 \%)$ & $1-6$ mutations: $5(16.7 \%)$ \\
& $>6$ mutations: $0(0 \%)$ & $>6$ mutations: $18(60 \%)$ \\
ISDR sequence & Range: $0-6$ & Range: $0-17$ \\
& wt: $20(66.7 \%)$ & wt: $7(23.3 \%)$ \\
& 1mutation: $10(33.3 \%)$ & 1 mutation: $2(6.7 \%)$ \\
TGF- $\beta 1$ (pg/ml) & $\geq 2$ mutations: $0(0 \%)$ & $\geq 2$ mutations:: $21(70 \%)$ \\
ICAM-1 (ng/ml) & Range: $0-1$ & Range: $0-7$ \\
& Range: $5,700-16,500$ & Range: $1,570-10,800$ \\
& Range: $210-1580$ & Range: $170-560$ \\
\hline
\end{tabular}


Figure.1 Schematic Representation of the Amino Acids Sequence of the Amplified Ns5a Region ㅇํㅇㅎㅠ

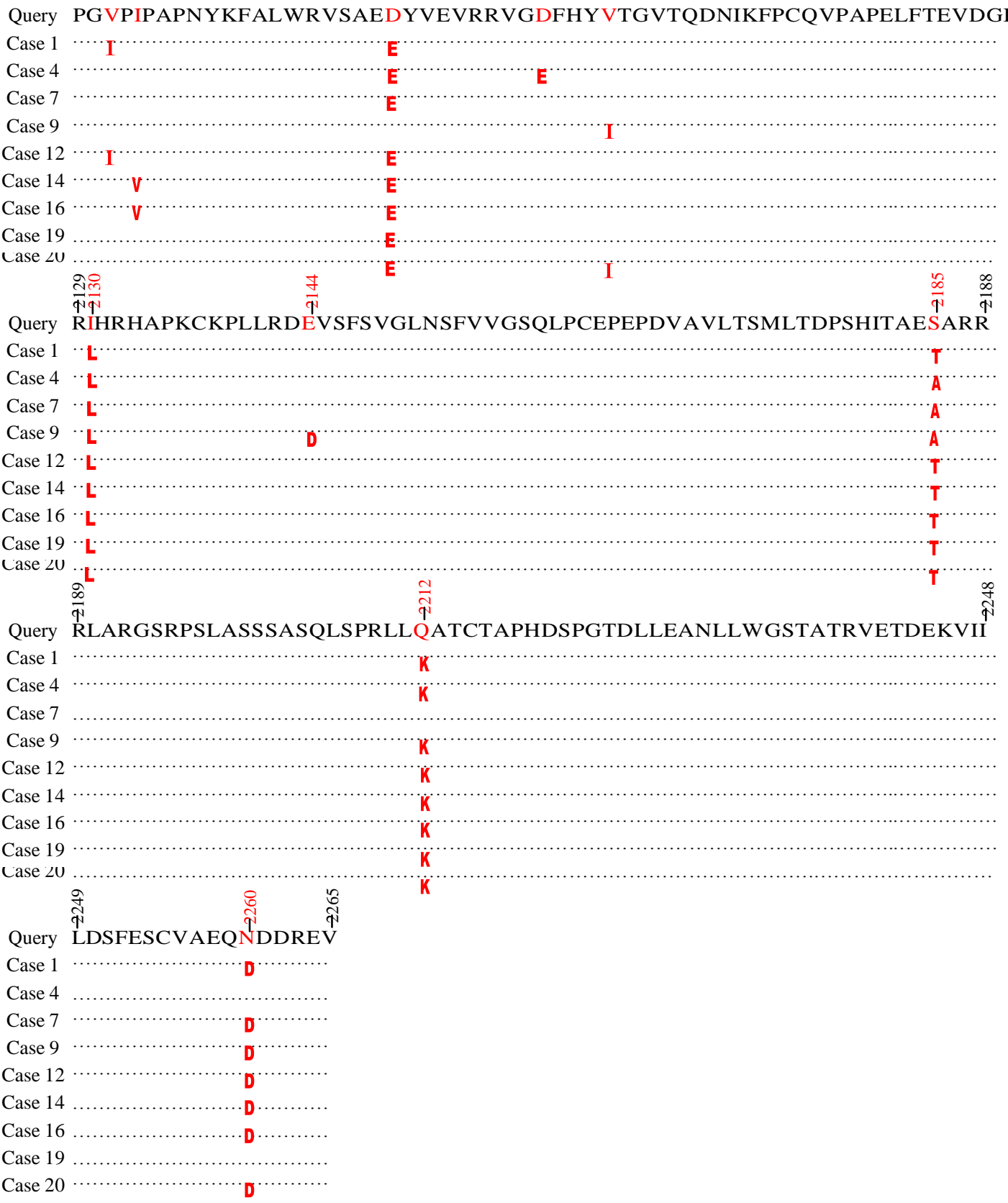

Query : wild type NS5A genotype 4a from gene bank 
Table.2 Comparative Statistics between Group I and Group II Patients as Regards the Studied Parameters

\begin{tabular}{|c|c|c|c|c|c|}
\hline & $\begin{array}{c}\text { Group I } \\
(n=30) \\
\text { Mean }+ \text { S.D }\end{array}$ & $\begin{array}{c}\text { Group II } \\
(n=30) \\
\text { Mean }+ \text { S.D }\end{array}$ & $\mathbf{t}$ & $\mathbf{p}$ & Significance \\
\hline $\begin{array}{l}\text { Number of NS5A } \\
\text { mutations/case }\end{array}$ & $1.97 \pm 0.47 *$ & $6.60 \pm 5.06$ & -4.679 & $<0.001$ & $\mathrm{HS}^{* *}$ \\
\hline Sequence identities (\%) & $96.6 \pm 3.31$ & $91.6 \pm 5.76$ & -3.99 & $<0.001$ & $\mathrm{HS}^{* *}$ \\
\hline $\begin{array}{l}\text { Number of ISDR } \\
\text { mutations/case }\end{array}$ & $0.33 \pm 0.087^{*}$ & $2.33 \pm 1.79$ & -5.222 & $<0.001$ & $\mathrm{HS}^{* * *}$ \\
\hline TGF- $\beta 1$ (pg/ml) & $9971 \pm 2554$ & $5708+2331$ & 7.009 & $<0.001$ & $\mathrm{HS}^{* *}$ \\
\hline ICAM-1 (ng/ml) & $633+331$ & $339 \pm 108$ & 4.626 & $<0.001$ & $\mathrm{HS}^{* *}$ \\
\hline
\end{tabular}

*Std Error of Mean (SEM) $\quad * *$ HS: highly significant

Table.3 Comparative Statistics between Group I and Group II Patients Who had Ns5a Mutations as Regards the Studied Parameters

\begin{tabular}{|l|c|c|c|c|c|}
\hline & $\begin{array}{c}\text { Group I } \\
(\mathbf{n = 1 2}) \\
\text { Mean } \pm \text { S.D }\end{array}$ & $\begin{array}{c}\text { Group II } \\
(\mathbf{n = 2 3 )} \\
\text { Mean } \pm \text { S.D }\end{array}$ & $\mathbf{t}$ & p & Significance \\
\hline $\begin{array}{l}\text { Number of NS5A } \\
\text { mutations/case }\end{array}$ & $4.5 \pm 1.38$ & $9.5 \pm 3.01$ & -3.90 & 0.004 & $\mathrm{~S}^{*}$ \\
\hline Sequence identities (\%) & $91.5 \pm 1.31$ & $89.1 \pm 3.82$ & -2.21 & 0.054 & NS** $^{* *}$ \\
\hline $\begin{array}{l}\text { Number of ISDR } \\
\text { mutations/case }\end{array}$ & $1.0 \pm 0.0$ & $2.97 \pm 1.33$ & -3.631 & 0.008 & $\mathrm{~S}$ \\
\hline TGF- $\boldsymbol{\beta 1}(\mathbf{p g} / \mathbf{m l})$ & $9576 \pm 2028$ & $5913 \pm 2133$ & 2.528 & 0.021 & $\mathrm{~S}$ \\
\hline ICAM-1 (ng/ml) & $770.3 \pm 429$ & $327 \pm 105$ & 2.794 & 0.032 & $\mathrm{~S}$ \\
\hline
\end{tabular}

*S: significant

**NS: non significant

Figure.2 ROC Analysis Showing Cutoff Value of TGF- $\beta 1$ and ICAM- 1 to Discriminate between HCV-related HCC and Non HCC Patients

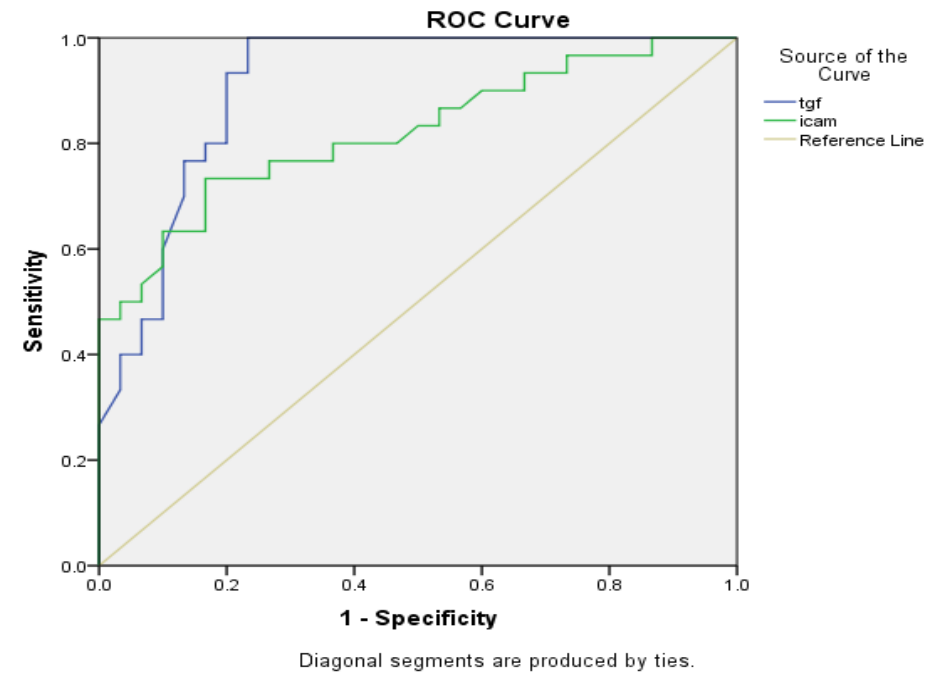


Chronically infected HCV patients have increased risk of developing HCC, which is directly correlated with the degree of liver damage and cirrhosis. In fact, HCC rarely occurs in non cirrhotic HCV patients, while the annual incidence rate of $\mathrm{HCC}$ in cirrhotic HCV patients is about 1 - 7\% (16). The development of markers for identification of $\mathrm{HCV}$ infected people who are at high risk of progressing to fibrosis and developing $\mathrm{HCC}$ is thus of ultimate importance.

The HCV NS5A protein is thought to play a critical role in viral replication and assembly, inhibition of response to interferon, and hepatocarcinogenesis, which makes NS5A an appealing target for novel anti-HCV therapies (12). The difference in the viral load, clinical sequence of $\mathrm{HCV}$ infection, progression to cirrhosis and $\mathrm{HCC}$ development can thus be attributed to genetic differences in the sequence of $\mathrm{HCV}$ NS5A region which varies in different $\mathrm{HCV}$ genotypes, and as far as we know, no such study has been performed on Egyptian patients. In that context, sequence analysis of the amplified NS5A region was performed in both $\mathrm{HCV}$-related $\mathrm{HCC}$ patients and chronic $\mathrm{HCV}$ non-HCC patients in the present study to highlight the potential pathogenic role of NS5A in the development of HCV-related HCC. We demonstrated that 18 patients $(60 \%)$ out of 30 patients of HCV-related HCC group (group I) harbored a wt sequence of NS5A region with sequence identities (100\%), while only $7 / 30$ of the non HCC chronic HCV patients group (23.3\%) harbored a wt sequence of NS5A region with a significant difference between both groups $(p=0.003)$, and that $23 / 30$ patients within the non $\mathrm{HCC}$ group (group II) harbored mutations in NS5A region that ranged from 5-17 with an average $9.5 \pm 3.01$ mutations and mean sequence identities $(89.1 \%)$, while the $12 / 30$ patients of the HCC group (group I) harbored mutations that ranged from 2 - 6 with an average $4.5 \pm$ 1.38 mutations and sequence identities $(91.5 \%)$. These results are in agreement with the results of other previous studies $(17,18,19)$, who reported that a significant majority of HCC patients had wild-type or minimally mutated NS5A protein, without substantial differences between tumor, liver tissue and serum, and suggested that the wt NS5A protein would probably have a role in $\mathrm{HCV}$-related liver carcinogenesis.

Experimental evidences suggest that HCVNS5A protein with a wt ISDR sequence (Codons 2209-2248) may contribute to the response to interferon based therapies, uncontrolled cell proliferation, and malignant transformation $(18,19)$. This is enforced by the findings in the present study, indicating that there was a significant increase in mean number of mutations in ISDR region $(p<0.001)$ in group II compared to group I, and that fewer mutations in the NS5A- ISDR, and wild type amino acid in this region were significantly correlated with HCC. Similarly, Hung and his associates (19), who investigated the association of risk of HCC development with the variation in the amino acid sequence in the NS5A-ISDR region, found that $\mathrm{HCC}$ was significantly associated with fewer amino acid substitutions in the NS5AISDR region, and that those patients who had $\geq 4$ mutations in NS5A-ISDR region had a lower prevalence of HCC than those patients with few $(<4)$ or no mutations (wild type) in this region, and suggested that amino acid substitutions in ISDR is a significant factor associated with the development of HCC in chronic HCV-1b patients. Meanwhile in our study, we found that only $10 / 30$ group I patients had mutations in the ISDR region and none of them had more than 1 ISDR mutation, while 23/30 group II patients had ISDR mutations ranging from $1-7$ with mean $2.97 \pm 1.33$ 
with a significant difference between both groups, and we suggest that NS5A-ISDR mutations $<2$ has a significant association with HCV-related HCC in Egyptian patients with genotype $4 \mathrm{a}$.

Based on these results, it is evident that NS5A wt sequence would indeed increase the risk for $\mathrm{HCV}$ associated $\mathrm{HCC}$ and thus could be used as a marker to identify $\mathrm{HCV}$ patients who are at risk to develop HCC and thus should be subjected to therapy in early phases before development of cirrhosis as it was reported that achieving sustained virological response in presence of cirrhosis would not abolish the risk of developing HCC (20).

The mechanism by which wt NS5A increases the risk of $\mathrm{HCC}$ is not fully elucidated (21), however it may involve escape from apoptosis, which is a crucial event that favors HCV survival and promotes hepatocarcinogenesis, by inhibition of caspase-3, activation of cellular proliferative pathways as RAf/MAPK/ERP pathway, and inducing mitotic dysregulation and chromosomal instability $(16,21)$.

In conclusion, the wild type NS5A, particularly that of ISDR regions, is a significant marker for the development of HCV-related HCC. In addition, high levels TGF- $\beta 1$ and ICAM- 1 are potential effective serological markers for the diagnosis of patients with HCV-related HCC.

\section{References}

1. Xuan SY, Xin YN, and Chen H (2007): Significance of hepatitis B virus surface antigen, hepatitis $\mathrm{C}$ virus expression in hepatocellular carcinoma and pericarcinomatous tissues. World $\mathbf{J}$ Gastroenterol; 13(12): 1870-1874.
2. Schmitz KJ, Wohlschlaeger J, and Long $H$ (2008): Activation of the ERK and AKT signaling pathway predict poor prognosis in HCC and ERK activation in cancer tissue is associated with $\mathrm{HCV}$ infection. Hepatology; 48 : 83-90.

3. Hiotis SP, Rahbari NN, Villanueva GA, Klegar E, Luan W, Wang Q, and Yee HT (2012): Hepatitis B vs. hepatitis C infection on viral hepatitis-associated hepatocellular carcinoma. BMC Gastroenterol; 12: 64.

4. Amal Ahmed Mohamed, Tamer A Elbedewy, Magdy El-Serafy, Naglaa El-Toukhy, Wesam Ahmed, Zaniab Ali El Din (2015): Hepatitis C virus: A global view. World J Hepatol; 7(26): 2676-2680.

5. Li T, Zhao S, Song B, Wei Z, Lu G, Zhou J, and Huo T (2015): Effects of transforming growth factor $\beta$ - 1 infected human bone marrow mesenchymal stem cells on high- and low-metastatic potential hepatocellular carcinoma. Eur J Med Res; 20: 56.

6. El-Zanaty F and Way A (2009): Egypt Demographic and Health Survey 2008. Cairo: El-Zanaty and Associates, and Macro International.

7. Miller FD, Elzalabany MS, Hassani S, and Cuadros DF (2015): Epidemiology of hepatitis $\mathrm{C}$ virus exposure in Egypt: Opportunities for prevention and evaluation. World J Hepatol; 7(28): 2849-2858.

8. Anwar MI, Iqbal M, Yousef MS, and Rahman M (2013): Over-expression and characterization of NS3 and NS5A of Hepatitis $\mathrm{C}$ virus genotype $3 \mathrm{a}$. Microb Cell Fact; 12: 111.

9. Farag MM, Sofy AR, Mousa AA, Ahmed MA, and Alganzory MR (2015): Molecular Assay and Genotyping of Hepatitis C Virus among Infected Egyptian and Saudi Arabian Patients. Virology (Auckl); 6: 1-10. 
10. Li HC and Lo SY (2015): Hepatitis C virus: Virology, diagnosis and treatment. World J Hepatol; 7(10): 1377-1389.

11. Goldberg - Bittman L, Kitay - Cohen Y, and Ruth Hadari (2008): Random aneuploidy in chronic hepatitis $\mathrm{C}$ patients. Cancer Genetics and Cytogenetics; $108:$ 20-23.

12. Igloi Z, Kazlauskas A, Saksela K, Macdonald A, Mankouri J, and Harris M (2015): Hepatitis C virus NS5A protein blocks epidermal growth factor receptor degradation via a proline motif- dependent interaction. J Gen Virol; 96(8): 2133-2144.

13. Saxena R and Kaur J (2015): Th1/Th2 cytokines and their genotypes as predictors of hepatitis B virus related hepatocellular carcinoma. World J Hepatol; 7(11): 1572- 1580.

14. Zhu PP, Yuan SG, Liao Y, Qin LL, and Liao WJ (2015): High level of intercellular adhesion molecule-1 affects prognosis of patients with hepatocellular carcinoma. World J Gastroenterol; 21(23): 7254-7263.

15. Zhu XW and Gong JP (2013): Expression and role of ICAM-1 in the occurrence and development of hepatocellular carcinoma. Asian Pac J Cancer Prev; 14: 1579-1583.

16. Goossens N and Hoshida Y (2015): Hepatitis $\mathrm{C}$ virus-induced hepatocellular carcinoma. Clin Mol Hepatol; 21(2): 105-114.

17. De Mitri M.S, Morsica G, and Cassini R (2002) : Prevalence of wild - type in NS5A - PKR protein kinase binding domain in HCV-related hepatocellular carcinoma. J Hepatology; 36: 116-122.

18. De Mitri M.S, Cassini Romina, and Bagalio Sabiina (2007): Evolution of $\mathrm{HCV}-\mathrm{NS} 5 \mathrm{~A}$ gene in the progression of liver disease to hepatocellular carcinoma. Liver International; 8: 11261133.

19. Hung $\mathrm{CH}$, Chen $\mathrm{CH}$, Lee $\mathrm{CM}, \mathrm{Wu} \mathrm{CM}$, $\mathrm{Hu} \mathrm{TH}$, Wang JH, Yen YH, and Lu SN (2008): Associations of amino acid variations in the NS5A and E2-PePHD region of hepatitis $C$ virus $1 b$ with hepatocellular carcinoma. Journal of Viral Hepatitis; 15: 58-65.

20. Bruno S, Crosignani A, Roffi L, De Lisi S, Rossi S, Boccaccio V, Zermiani P, Mondelli M, and Maisonneuv $\mathrm{P}$ (2014): SVR is associated with no risk reduction of $\mathrm{HCC}$ development in patients with $\mathrm{HCV}$-related cirrhosis. A prospective, up to 23-years, cohort follow-up study. J Hepatology; 60(Suppl): S224.

21. Cheng D, Zhang L, Yang G, Zhao L, Peng F, Tian Y, Xiao X, Chung RT, and Gong $G$ (2015): Hepatitis $C$ virus NS5A drives a PTEN-PI3K/Akt feedback loop to support cell survival. Liver Int; 35(6): 1682-1691.

22. Zhao YJ, Ju Q and Li GC (2013): Tumor markers for hepatocellular carcinoma. Mol Clin Oncol; 1: 593598.

23. Dong ZZ, Yao DF, Yao M, Qiu LW, Zong $\mathrm{L}, \mathrm{Wu} \mathrm{W}, \mathrm{Wu} \mathrm{XH}$, Yao DB, and Meng XY (2008): Clinical impact of plasma TGF-beta1 and circulating TGF-beta1 mRNA in diagnosis of hepatocellular carcinoma. Hepatobiliary Pancreat Dis Int; 7(3): 288-295.

24. Yasmin Anum MY, Looi ML, Nor Aini AH, Merican I, Wahidah A, Mohd Radzi AH, Nor Azizah A, and Othman NH (2009): Combined assessment of TGF-beta-1 and alpha-fetoprotein values improves specificity in the diagnosis of hepatocellular carcinoma and other chronic liver diseases in Malaysia. Med J Malaysia; 64(3): 223227. 
25. Zhang H, Liu L, Wang Y, Zhao G, Xie $\mathrm{R}$, Liu C, Xiao X, Wu K, Nie Y, Zhang H, and Fan D (2013): KLF8 involves in TGF-beta-induced EMT and promotes invasion and migration in gastric cancer cells. J Cancer Res Clin Oncol; 139(6): 1033-1042.

26. Lin TH, Shao YY, Chan SY, Huang CY, Hsu CH, and Cheng AL (2015): High Serum Transforming Growth Factor- $\beta 1$ Levels Predict Outcome in Hepatocellular Carcinoma Patients Treated with Sorafenib. Clin Cancer Res; 21(16): 3678-3684.

27. Ma J, Liu YC, Fang Y, Cao Y, and Liu ZL (2015): TGF- $\beta 1$ polymorphism 509 $\mathrm{C}>\mathrm{T}$ is associated with an increased risk for hepatocellular carcinoma in HCVinfected patients. Genet Mol Res; 14(2): 4461-4468.

28. Zekri AR, Youssef AS, Bakr YM, Gabr RM, El-Rouby MN, Hammad I, Ahmed EA, Marzouk HA, Nabil MM, Hamed HA, Aly YH, Zachariah KS, and Esmat G (2015): Serum Biomarkers for Early Detection of Hepatocellular Carcinoma Associated with $\mathrm{HCV}$ Infection in Egyptian Patients. Asian Pac J Cancer Prev; 16(3): 12811287.

\section{How to cite this article:}

Dina ElShennawy, Nermeen Tayseer Aly Fouad, Hanaa Amer, Amal T Abdel Moez, Hanaa Fathey, Marcel W Keddeas and Elewa AA. 2016. Markers of HCV-Related HCC in Egyptian Patients. Int.J.Curr.Microbiol.App.Sci.5(2): 752-762.

doi: http://dx.doi.org/10.20546/ijcmas.2016.502.085 